\title{
Afterword
}

\section{Maintaining Social Order}

The starting point of most discussions of the law is compliance, since the purpose of creating laws and empowering legal authorities is to establish and maintain social order by regulating public behavior. The issue addressed by Why People Obey the Law is how such compliance can best be achieved. During the past several decades the dominant approach to securing compliance has been through the threat or use of punishment-that is, via deterrence. The use of deterrence was ubiquitous at the time this book was written in the 1980s, and it has remained the dominant approach to maintaining social order into the twenty-first century (Nagin 1998).

Deterrence strategies are one example of instrumental strategies, which are based upon the assumption that the primary factors motivating human behavior are incentives and sanctions. In the context of regulation, this vision leads to a deterrence strategy, linking sanctions to rule breaking, while in the organizational literature it leads to a view that performance is enhanced via incentives, with desired performance linked to the provision of rewards (Tyler and Blader 2000).

One argument in favor of using deterrence as an approach to securing com pliance is that it is a strategy that works. Interestingly, as research has accumulated about the influence of risk assessments on law-related behavior, this general assertion has been widely qualified. Studies suggest that deterrence sometimes significantly influences law-related behavior, and sometimes does not. In fact, one finding of Why People Obey the Law, a result typical of studies in this area, is that once other factors are accounted for, there is no significant influence of risk-related judgments on compliance with the law. Further, even when risk is found to have an influence, the magnitude of that influence is small. For example, in a review of studies of drug use, MacCoun (1993) estimates that only around 5 percent of the variance in drug-use behavior is explainable through variations in risk estimates.

In addition to mixed evidence regarding effectiveness, the widespread use of deterrence approaches has led to serious negative side effects (Tyler 1997a, 1998, 2003). One such side effect is the dramatic growth in the American prison population, leading the United States to be a world leader in the proportion of its population that is incarcerated. Further, since deterrence policies are directed primarily at the disadvantaged, their use has undermined police-community relations in ur- 
ban areas, and especially among minority groups. One of the largest and most consistent findings in public opinion polling is that of lower trust and confidence in legal authorities among minority group members than among whites.

Are there alternative ways to secure compliance that do not have these negative side effects? At the time this book was written, legitimacy was discounted as a factor that shaped compliance. In a then-recent and widely cited review Hyde (1983) argued that there was no convincing evidence that legitimacy had behavioral effects. In the absence of evidence of the efficacy of values such as legitimacy, deterrence seemed to be the only viable approach to managing problems of social order.

The goal of Why People Obey the Law was to articulate and defend empirically an alternative vision of social order maintenance linked to gaining the consent and cooperation of the public with the law and legal authorities. This alternative vision unfolded in three stages, and, at each stage, the results of analysis on the panel study of the residents of Chicago were used to provide empirical support for this alternative noninstrumental vision. The first stage demonstrated that legitimacy shapes compliance with the law. The second stage showed that legitimacy was not based upon instrumental judgments but was rooted in procedural justice judgments. And, finally, the third stage explored the meaning of procedural justice, making clear that respondents defined procedural justice in reference to noninstrumental issues. Taken together, these findings supported the argument that people's motivation to cooperate with others, in this case legal authorities, is rooted in social relationships and ethical judgments, and does not primarily flow from the desire to avoid punishments or gain rewards.

This broad theme of noninstrumentality has been increasingly articulated throughout the social sciences in the decades since the original publication of Why People Obey the Law. Those writing in political science and public policy (Green and Shapiro 1994) and management (Pfeffer 1994) have noted the difficulties of effective governance via only instrumental approaches.

\section{Legitimacy and Compliance}

The first scholarly contribution of Why People Obey the Law was to provide empirical support for the value of legitimacy as a motivating force in the area of law. In fact, the findings of this study suggested that legitimacy was more influential than was the risk of being caught and punished for rule breaking.

While Why People Obey the Law did not distinguish between and distinctly measure compliance and deference, one implication that flowed from the important role of legitimacy in shaping law-related behavior was the differentiation between the compliance that occurs in response to the risk of punishment and 
the deference that results from legitimacy. Deference was argued to flow from people's desire to do what they felt they ought to do in a particular situation. As a result, people were expected to follow rules even when the risk of being caught and punished was low or nonexistent. In other words, they become self-regulatory, taking the responsibility for rule following onto themselves. In recent years scholars have increasingly articulated the value of promoting self-regulatory approaches to rule following throughout the legal community, and the findings of Why People Obey the Law provide one source of empirical support for the viability of those arguments.

At the time that Why People Obey the Law was written, the conception of the relationship between community residents and legal authorities was a reactive one, with obedience to legal rules viewed as the key behavior that legal authorities wanted from those in the community. Since that time it has been recognized that authorities need the more active cooperation of those in the community (Sunshine and Tyler 2003; Tyler 2002, 2003). Recent studies of community efforts to combat crime and urban disorder, for example, demonstrate that the police benefit from the active cooperation of people in neighborhoods (Sampson, Raudenbush, and Earls 1997).

Beyond the area of regulation, there has been an increasing recognition that groups, organizations, and communities benefit when their members willingly cooperate with authorities and institutions (see Darley, Messick, and Tyler 2001; Van Vugt, Snyder, Tyler, and Biel 2000). The role of cooperation in efforts to fight crime and disorder is only one example. The large movement on the value of social capital for communities that has developed in recent years argues that it is important for people to have the types of associations with others that build trust and encourage active participation (Putnam 2000). Researchers have also shown the significance of voluntary extra-role behaviors to the effectiveness of work organizations (Tyler and Blader 2000). Hence, the importance of being able to engage people's internal motivations has become more widely recognized, and extends well beyond the issue of compliance with the law.

In focusing on gaining everyday compliance with the law, Why People Obey the Law considered a wide variety of potentially relevant types of compliance, ranging from paying taxes to stopping at red lights. And, of course, this examination occurred during an era in which the willingness to defer to government policies was very much at issue for a variety of reasons, including the aftermath of the war in Vietnam and government scandals such as Watergate (Levi 1997). In more recent years, issues of compliance with the law have continued to be important, but their focus has shifted, with increasing attention paid to the areas of drugs and intellectual property. In the case of intellectual property, the widespread copying and downloading of illegal software, music, and movies has 
again illustrated the difficulties of gaining deference toward the law through the use of sanctions (Jensen 2003; Tyler 1997b).

Concerns about rule following have also become important in work organizations, in response to recent corporate ethics scandals. These have led to a focus on corporate governance. In the past few years a number of instances of corporate misconduct, such as the accounting scandals at Enron and Tyco, have come to public attention (Ivancevich, Duening, Gilbert, and Konopaske 2003). These have raised the question of how to govern businesses so as to keep their conduct within the law. This concern highlights the enduring importance of the question of how to manage groups, organizations, and societies. In the case of managing business, both business and government are involved. Businesses might potentially manage themselves internally, or they might be externally regulated by government, or a combination of both. In any case, the question is how to effectively bring conduct into line with rules.

Using a conceptual framework drawn from Why People Obey the Law, Tyler and Blader (2005) explored this issue within two samples of employees. One was a sample of corporate employees, the other a random sample of American workers. In both they found that the legitimacy of corporate rules was a key antecedent of corporate conduct. Employees followed policies and obeyed rules when they viewed the corporation as legitimate and entitled to be obeyed. This influence was distinct from that of sanction-related risks of rule breaking. Employees were also influenced by their judgments about the degree to which the policies of their companies were consistent with their own moral values. In the work context, these findings point to the possibility of self-regulation, suggesting that businesses can effectively secure the deference of their employees to their policies and rules when they are viewed as legitimate authorities who are acting in ways consistent with their employees' moral values (see also Tyler 2005).

\section{The Basis of Legitimacy: Procedural Justice}

The second important argument made in Why People Obey the Law is that the basis of legitimacy is the justice of the procedures used by legal authorities. The same instrumentalism that underlies strategies of deterrence has been important in shaping the framework through which legitimacy has traditionally been understood. People have been viewed as being loyal toward and supporting those authorities and institutions that create desirable, or at least just, policies. This perspective is found in models arguing that people evaluate authorities based upon their performance, that is, upon their delivery of desired resources and policies. According to an instrumental perspective, the police and 
courts gain legitimacy by being effective in fighting crime; political leaders are evaluated upon their success in shaping economic performance; and workers follow those managers who lead their companies to success.

Why People Obey the Law adopts a different framework within which to evaluate legitimacy. That framework is not linked to either the favorability or fairness of the decisions made or policies pursued by legal authorities. Rather, legitimacy is linked to the justice of the procedures by which the police and courts implement the law. This procedural justice perspective was not a new one when Why People Obey the Law was written, since Thibaut and Walker's work on adversary and inquisitorial trials (1975) had already demonstrated its relevance to law. However, Why People Obey the Law broadened the focus of this research to include a consideration of people's views about the overall legitimacy of the law and legal authorities, rather than only upon reactions to particular decisions. It showed that, in this arena, procedural justice was also important.

The broadened focus represented by a concern about legitimacy connected the study of procedural justice to the key question of why people view societal rules, authorities, and institutions as entitled to be obeyed. In his classic work on authority (1968), Weber articulated this question and identified several reasons why authority might be obeyed. The most relevant reason in contemporary Western societies is because authority is exercised rationally, that is, in ways broadly consistent with principles of procedural justice. Hence, the link between procedural justice and legitimacy, which is shown empirically in Why People Obey the Law, connects to an important stream of twentieth-century social theory (see also Selznick 1969).

As noted above, one limitation of the original study described in Why People Obey the Law was that it did not focus on decision acceptance during personal encounters with police officers or judges. In this way, it did not directly follow from the earlier work of Thibaut and Walker (1975). This neglected issue was addressed by Tyler and Huo (2002) in a study of personal encounters with police officers and judges in Los Angeles and Oakland. Their study, which measured both compliance and deference, found that procedural justice was central to the willingness to defer to decisions. It was further shown that procedural justice effects were strongest when the issue was voluntary deference. People complied in response to the threat or use of force, and deferred in response to procedural justice.

Since the publication of Why People Obey the Law, the study of procedural justice has gained momentum, and, today, there is a large body of literature linking procedural justice to authority relations in law, politics, management, and even with interpersonal relations (Lind and Tyler 1988; Tyler 2000b; Tyler and Blader 2000; Tyler, Boeckmann, Smith, and Huo 1997; Tyler and Smith 1998). People are widely found to react to the fairness by which authorities and institutions make de- 
cisions and exercise authority, and these reactions shape both their willingness to accept decisions and their everyday rule-following behavior. In addition, these effects have been found to occur when substantial issues, such as personal freedom, are involved (Casper, Tyler, and Fisher 1988; Tyler, Casper, and Fisher 1989).

One important change within the procedural justice literature has been a broadened focus of concern. Early studies, such as Why People Obey the Law, shaped their concerns in terms of the need to gain compliance, and focused on the role of legitimacy and procedural justice in shaping rule adherence. Subsequent studies have strongly supported the argument that procedural justice shapes reactions to decisions (Tyler and Huo 2002); to rules (Jackson and Fondacaro 1999; Kim and Mauborgne 1991, 1993; Sparks, Bottoms, and Hay 1996; Tyler 2004b; Tyler and Degoey 1995); and to policies (Smith and Tyler 1996). This pertains not only to legal authorities and institutions, but to the political arena as well (Farnsworth 2003; Gangl 2003; Hibbing and Theiss-Morse 2002).

The early focus on fair decision-making procedures coincided with efforts within the legal system to gain acceptance for the decisions made by legal authorities, in particular judges. Hence, most of the initial studies, including the pioneering work of Thibaut and Walker (1975), focused on how to gain deference to judicial decisions. Research supported by the American Bar Foundation, including some of the data collection for Why People Obey the Law, concentrated on understanding why people were dissatisfied with the legal system and its procedures for resolving disputes.

A response to such dissatisfaction, and one that is consistent with the message of procedural justice research, is the development of the alternative dispute resolution movement, which emphasizes the use of informal dispute resolution mechanisms such as mediation (Tyler 1987b, 1988b, 1997a). As the importance of perceived procedural justice has been recognized, the legal system has increasingly shaped its dispute resolution institutions in ways that divert cases toward mediation. This has led to increased satisfaction with the legal system, and the greater willingness of disputants to defer to third-party dispute resolution decisions.

Issues of procedural justice have also become important as part of the efforts in work settings to create effective systems of corporate governance. As previously noted, studies of employees show that they are motivated by their evaluations of the legitimacy of corporate rules (Tyler and Blader 2005). These same studies show that, as in community settings, the legitimacy of policies and rules in work settings is strongly linked to employee evaluations of the fairness of corporate procedures. If companies act in ways that employees experience as procedurally just, their rules are viewed as more legitimate, and are more likely to be obeyed.

More recent research moves beyond issues of deference to decisions and rules and recognizes that it is also important that people actively work on behalf 
of groups, organizations, and communities. This has focused attention on the facilitative influence of procedural justice on satisfaction, intrinsic motivation, commitment to groups, and the willingness to be creative and engage in voluntary behaviors to help those groups (Colquitt, Conlon, Wesson, Porter, and Ng 2001). Interestingly, the research literature suggests that procedural justice is a key antecedent of both types of behavior. Through legitimacy, procedural justice encourages deference. Procedural justice also leads to satisfaction, commitment, and intrinsic motivation, and through them to efforts to be creative and to find voluntary actions that can help groups be successful. Hence, subsequent research confirms the importance of exercising authority fairly.

One particularly valuable aspect of subsequent studies is the linkage of procedural justice and legitimacy to the maintenance of behavior over time. One problem with compliance based upon deterrence is that changes in behavior are not maintained when the risk of punishment diminishes or disappears. In contrast, behavior linked to legitimacy, and hence to procedural justice, is expected to be better maintained over time. Studies have supported this argument. For example, research on adherence to mediation agreements over time indicates that people are more likely to adhere to agreements that are made using fair procedures (Pruitt et al. 1993). Further, those who experience fair procedures when dealing with the police are more likely to comply with the law into the future (Paternoster et al. 1997). It is in this ability to encourage self-regulation that the potential gains of procedural justice and legitimacy are most clearly revealed, and studies support the argument made in Why People Obey the Law that such self-regulation is possible.

While Why People Obey the Law focused directly upon issues of legitimacy and compliance in situations with well-established authorities and rules, recent procedural justice research suggests that the scope of procedural justice influence is much broader. The breadth of procedural justice influence is suggested in earlier laboratory studies (Barrett-Howard and Tyler 1986) which demonstrate that procedural justice dominates reactions to allocations across all types of social settings. This finding is reinforced by recent demonstrations that procedural justice is important in bilateral negotiations (Hollander-Blumoff and Tyler 2005); in markets (Sondak and Tyler in press); and even when people are dealing with service providers (Tyler in press).

\section{The Meaning of Procedural Justice}

As was true in the two prior sections of Why People Obey the Law, the final section contrasts instrumental and noninstrumental models through 
which the meaning of procedural justice can be understood. Early work on procedural justice, in particular that of Thibaut and Walker (1975), presented an instrumental, or control-based, interpretation of procedural justice findings. They argued that people define fair procedures as those in which they are given an opportunity to state their case before decisions are made. Their interpretation of this finding was that people's goal in disputes was to gain fair outcomes for themselves (i.e., to achieve distributive fairness). Since distributive fairness was defined in these studies by equity, it was necessary for the parties involved to have a chance to present their evidence. Absent this opportunity, it would not be possible for the decision maker to give each party what they deserved. Hence, the goal of a fair procedure was to produce a fair outcome.

Why People Obey the Law examined the psychology underlying procedural justice judgments and demonstrated that people's judgments could not be explained as a simple reflection of their indirect control over outcomes via evidence presentation. Rather, people valued the opportunity to speak to authorities and state their case, even when they did not think that their presentation would influence their outcome (Tyler, Rasinski, and Spodick 1985). The only condition under which people did not value this opportunity was when they did not believe that the authority was listening to and considering their arguments (Tyler 1987a).

Subsequent studies of procedural justice have broadened this conclusion about the importance of noninstrumental factors by showing that people place considerable importance on a variety of noninstrumental criteria. These have been labeled "relational criteria," since they provide people with feedback about the quality of their relationship with authorities and institutions (Tyler and Lind 1992). Relational criteria include assessments of the quality of interpersonal treatment (are people treated with dignity and respect? are their rights respected?) and evaluations of the trustworthiness of authorities, as well as judgments about the neutrality of decision making and the degree to which opportunities to participate are provided. Research strongly supports the argument that an important aspect of procedural justice involves these noninstrumental judgments (Tyler 1988a, 1989, 1994a; Tyler, Degoey, and Smith 1996).

The noninstrumentality of procedural justice concerns has been compellingly demonstrated in recent research in two ways. First, procedural justice judgments have been directly linked to judgments about the self-including assessments of personal self-worth and self-esteem (Tyler, Degoey, and Smith 1996). It has been shown that people care more strongly about procedural justice when their identities are linked to a social relationship with a group or person, but not when greater or fewer outcomes are at stake (DeCremer and Tyler 2005; Huo, Smith, Tyler, and Lind 1996; Smith and Tyler 1997; Tyler, Lind, Ohbuchi, Sugawara, and Huo 1998; Smith, Tyler, Huo, Ortiz, and Lind 1998). 


\section{The Social Implications of Why People Obey the Law}

The overall concern of Why People Obey the Law was with the relationship between people and authority. The study explored the conditions under which people were willing to defer to authorities, ceding to those authorities control over their behavior in particular settings. The question of how to create an effective system of social order is as old as organized society itself, and has been commented on for as long as social theorists have existed. One simple view is that authorities command others through their control of power. This view is as old as Thucydides, who argued that "The strong do what they will, the weak endure what they must," and as recent as Mao Tse-Tung, who said "Political power grows out of the barrel of a gun."

Why People Obey the Law articulated an alternative conception of the relationship between the government and the governed, between authorities and the people. This alternative view argued that authorities should govern based upon the consent of those that they govern, consent that develops from the experience of fairness when dealing with authorities. This fairness leads to legitimacy, a key precursor of consent and voluntary acceptance.

The suggestion that legitimacy is an alternative basis for governance is not a new one. Early social theorists writing as long ago as Aristotle and Plato recognized that seeking to gain influence over others based solely on the possession of power is costly and inefficient. The use of power, particularly coercive power, requires a large expenditure of resources to obtain modest and limited amounts of influence over others. It is therefore important that under some circumstances people are also influenced by others because they believe that the decisions made and rules enacted by others are in some way "right" or "proper" and ought to be followed (Zelditch 2001). In other words, subordinates also "relate to the powerful as moral agents as well as self-interested actors; they are cooperative and obedient on grounds of legitimacy as well as reasons of prudence and advantage" (Beetham 1991, 27).

The classic argument of political and social theorists has been that for authorities to perform effectively, those in power must convince everyone else that they "deserve" to rule and to make decisions that influence the quality of everyone's lives. In other words, every authority system tries to cultivate a belief in its legitimacy (Zelditch and Walker 2003). It is this belief - that some decision made or rule created by these authorities is "valid" in the sense that it is "entitled to be obeyed" by virtue of who made the decision or how it was made-that is central to the idea of legitimacy. While some argue that it is impossible to rule using only the control of resources that forms the basis of power, and others suggest 
that it is possible, but more difficult, it is widely agreed that authorities benefit from having legitimacy, and find governance easier and more effective when the feeling that they are entitled to rule is widespread within the population.

The findings of Why People Obey the Law support the argument that it is important for authorities and rules to be consented to, rather than imposed via sanctions or incentives. The results of the study support this argument on three levels. They first show that legitimacy is a distinct judgment that shapes rulerelated behavior. They then show that people use ethical judgments about the fairness of procedures to determine the legitimacy of authorities and institutions. Finally, procedural fairness itself is shown to be linked to noninstrumental issues that provide information about the nature and quality of people's interpersonal relationship with others. On all of these levels, the argument advanced is for a noninstrumental image of the relationship between the person and society, the person and the state.

Each of these themes has become more strongly supported in the years following the publication of Why People Obey the Law. The body of literature on legitimacy has become larger and more robust, with a number of studies supporting the argument that legitimacy shapes deference to decisions and rules. Many studies now support the centrality of procedural justice to evaluations of authorities and institutions, to the acceptance of decisions, and to everyday rulerelated behavior. Finally, the instrumental roots of procedural justice are not widely supported via research testing the arguments of the group-value model of procedural justice (Lind and Tyler 1988); the relational model of authority (Tyler and Lind 1992); and the group engagement model of cooperation (Tyler and Blader 2000, 2003).

\section{Intergroup Relations}

Why People Obey the Law based its conclusions on an ethnically diverse sample drawn from the city of Chicago. Based upon the analysis conducted, it was argued that the model outlined applied to both white and minority residents of the community. This argument was attacked on methodological grounds by suggesting that a more ethnographic approach to understanding disadvantaged respondents would yield clear differences in the manner that people think about the law (Sarat 1993). And, in fact, subsequent ethnographic approaches have yielded evidence that there may be differences in the way the law is conceptualized which are associated with race and class (Ewick and Silbey 1998).

While there may be class- or ethnicity-related differences in the way that 
people think about the law, subsequent efforts to identify major ethnicity-based differences in the framework outlined in Why People Obey the Law have consistently failed (Lind, Huo, and Tyler 1994; Lind, Tyler, and Huo 1997; Tyler 1994b, 2000a). Both white and minority respondents are influenced by legitimacy judgments, and base their assessments of the legitimacy of the police, the courts, and the law on the procedural justice of authorities.

The most extensive effort to address issues of ethnicity is Tyler and Huo (2002), which oversamples minorities to compare the psychology underlying the reactions of whites, African Americans, and Hispanics to personal experiences with police officers and judges. That study finds limited evidence of ethnic group differences, with the reactions of the members of all groups being well described by the model already outlined. This does not mean that there are not distinctions among the bases upon which the members of different ethnic groups react to legal authorities - there are. However, these differences are small in magnitude and occur against a backdrop of overwhelming similarity. In the work of Tyler and Huo (2002), for example, substantial ethnicity-based differences in willingness to defer to legal authorities are found. However, once psychological judgments are taken into account, the direct influence of ethnicity disappears.

This work has important implications for the arena of intergroup relations. If the members of different ethnic groups were not able to bridge differences in values and interests, it would be impossible to manage intergroup relations within an ethnically diverse society. Hence, it is important to demonstrate that the members of advantaged groups will support policies that help disadvantaged groups if those policies are enacted and implemented fairly, and that the members of disadvantaged groups will obey laws enacted by advantaged groups if those laws are enacted and implemented fairly. Smith and Tyler (1996) demonstrate that procedural justice is effective in both of these cases.

\section{Bridging Differences}

For justice to be effective in bridging differences it is also important that people agree upon what constitutes a just procedure. One of the strengths of a procedural justice-based strategy of regulation is that, while there are widespread differences in evaluations of the favorability or fairness of outcomes based upon race, class, ideology, and other similar factors, the members of American society generally exhibit widespread agreement both that procedural justice is key to legitimacy and in the issues they view as defining procedural 
justice (Tyler 1994b). Hence, one general approach that might profitably be taken to governance is to use "fair" procedures as a framework within which to manage contentious disputes.

The idea of frameworks that can bridge differences in background is central to discussions about the viability of multicultural societies. If a group of people differ in their ethnic or cultural backgrounds, a key question for governance is how those individuals can be held together when they have differing beliefs about what is appropriate or correct. This question is central to the efforts of democratic societies such as the United States and many European countries, which have substantial immigration from other societies, to maintain their viability. If people will defer to government institutions and authorities because of the procedures by which authority is exercised, then it is much easier to imagine that diverse, multicultural societies can be viable.

Building upon the themes in Why People Obey the Law, subsequent research by Tyler (1994b, 2000a) and his students has examined the degree to which such bridging actually occurs in multicultural settings. The findings of this research strongly support the argument that multicultural societies can be viable and that the key to that viability is identification with the superordinate group and its institutions and authorities. When people identify with superordinate authorities, they defer to laws and institutions based upon procedural justice judgments (Huo 2003; Huo, Smith, Tyler, and Lind 1996). This is true, irrespective of their degree of attachment to their ethnic or cultural subgroups.

Another arena in which this suggestion has taken hold is that of contentious public policy debates. One example involves land use and environmental regulation, areas in which emotional disputes are common. Stakeholder groups have been organized, with the various parties involved in disputes meeting together over long periods of time to seek consensus solutions to issues of division (Kenney 1999; Landsman 2003; Leach and Pelkey 2001; Leach, Pelkey, and Sabatier 2002). Over 3,500 such partnerships have been cataloged (EPA 2002). Another example is the use of public hearings to decide how to manage the land upon which the World Trade Center was situated (Tyler and Thorisdottir 2003). While these examples have nothing to do with ethnicity, they illustrate the argument that procedural justice can bridge differences, particularly differences in interests and ideologies.

\section{Political Implications}

Legitimacy is also an issue on the group, organizational, or system level, where the legitimacy of authorities and institutions is part of the overall 
climate or culture (Tyler 2006). Discussions of the stability of social and political systems have long emphasized the importance to effective governance of having widespread consent from those within the system (Easton 1965). Such widespread consent enables the more effective exercise of social and political authority, since authorities can appeal to members based upon their shared sense of values. As Kelman (1969) argues, "It is essential to the effective functioning of the nation-state that the basic tenets of its ideology be widely accepted within the population" (p. 278). Hence, effective governance depends upon the legitimacy of the state.

Across all types of organizations the core argument of legitimacy theory is that legitimacy provides a "reservoir of support" for institutions and authorities, something besides immediate self-interest, which shapes reactions to their policies (Easton 1965; Tyler 2006). Such a reservoir is of particular value during times of crisis or decline, when it is difficult to influence people by appealing to their immediate self-interest, and when risks about the long-term gains associated with belonging to the group are salient. Recent research supports this "reservoir of support" argument. Studies of the 2000 U.S. Supreme Court decision in Bush v. Gore suggest that in gaining deference for a controversial decision the Court benefited from the widespread public view that the Court is a legitimate political institution (Gibson, Caldiera, and Spence 2003).

Many recent changes in various governments around the world, including those in South Africa and the former Soviet republics, have provided additional field settings within which the underlying assumptions of legitimacy theory have been tested. These changes in government have also rekindled interest in understanding how to create and maintain institutional legitimacy, since issues of social disintegration and internal conflict become salient when governments collapse and new forms of social order must be created. This renewed emphasis on understanding how to legitimate new governments is consistent with the earlier "major preoccupation of political scientists and sociologists [with legitimacy] in the post-colonial, nation-building era after the Second World War" (Sears 2003, 323). That preoccupation with establishing legitimacy was fueled by the fear that, without legitimate authorities and institutions, societies would descend into anarchy and chaos.

This political perspective is that, when a new government comes into being, a key factor shaping its success is the degree to which it can establish legitimacy among the general populace. As Gibson argues, "In a new political system few resources are more coveted than political legitimacy. Legitimacy is an endorphin of the democratic body politic; it is the substance that oils the machinery of democracy, reducing the friction that inevitably arises when people are not able to get everything they want from politics. Legitimacy is loyalty; it is a reservoir 
of goodwill that allows the institutions of government to go against what people may want at the moment without suffering debilitating consequences" (Gibson 2004, 289). For this reason, those seeking to solidify their exercise of authority do so by creating institutions that will receive public support (Trochev 2004).

Research on emerging governments supports the argument that political institutions, including courts, can legitimate and gain acceptance for unpopular decisions and policies (Gibson 2002; Gibson, Caldiera, and Baird 1998; Gibson, Caldiera, and Spence 2005; Machura 2003). On the other hand, studies also raise questions about the breadth of such legitimation effects. Gibson and Caldiera (2003), for example, find that the Constitutional Court in South Africa has little power to legitimate unpopular decisions. In more established societies, such as the United States, courts seem to be well able to legitimate controversial policies. Tyler and Mitchell (1994), for example, use abortion policy to demonstrate the power of the U.S. Supreme Court to legitimate unpopular policies.

Of course, while the positive consequences of legitimacy are important, it is essential to note that legitimacy can serve as the basis for justifying the oppression and harming of others. The potential risks of legitimacy are treated at length by Kelman and Hamilton (1989) and Kelman (2001). In particular, because people authorize another to make judgments for them about what is appropriate conduct, they no longer feel that their own moral values are relevant to their conduct. As a consequence, when directed by that legitimate authority to engage in immoral actions, people are found to be strikingly willing to do so (Kelman 2001).

Psychological research has focused on legitimacy as a form of power, and explored when legitimacy shapes people's thoughts, feelings, and behavior. However, the recent emphasis of legitimacy research on societal-level institutions highlights the importance of social theories in shaping the normative perspective that is taken when studying legitimacy. That perspective must, of necessity, be rooted in political and sociological theories about the social nature of societies (Parkin 1972).

The views of many classic social theorists are linked to the underlying assumptions of consensus views of society (Dahl 1956; Easton 1965; Lipset 1959; Parsons 1967; Sears 2003). Those views argue that all members of society benefit from the social and political stability that is facilitated by widespread views that existing authorities and institutions are legitimate. Hence, there is no fundamental societal conflict underlying the study of legitimacy. Legitimacy is a valuable attribute for an institution if it promotes acceptance of its decisions and the rules it promulgates.

The primary question of concern from a consensus perspective has been when 
and to what degree legitimacy actually shapes behavior. The focus of rational actor models on the influence of rewards and punishment on behavior has led to a concentration on those factors, rather than on the development and maintenance of values such as legitimacy as part of a focus on the importance of political culture (Green and Shapiro 1994). Earlier writers argued that the key to a stable society was the widespread development of such values (Easton 1965), leading to a focus in their research on the socialization of supportive values such as legitimacy and support for legal and political authority (Easton and Dennis 1969; Hess and Torney 1967; Hyman 1959).

An alternative view of the society develops from "conflict theories" of society, models rooted in Marxism, but equally consistent with both realistic group conflict theory and, more recently, social identity theory. These models argue that groups within society are in conflict over valued resources and favored identities. Each group seeks to gain dominance over others, with the result that institutional arrangements and legitimizing ideologies favoring one group are often not beneficial to those within other groups.

This view of society leads to the argument that the process of legitimation favors the dominant group over others. It is not in the interest of subordinate groups to defer to the authorities and institutions that dominant groups have created to serve their interests. Hence, from this perspective, widespread deference to legitimate authorities is beneficial only to those in the dominant group, who seek to perpetuate their privileges by creating ideologies, myths, and rituals that legitimate their favored position. Subordinate groups would be better off rejecting existing authorities and institutions and challenging the status quo by seeking social change.

Such conflict-based models of society underlie many of the contributions in a recent volume on the psychology of legitimacy, Jost and Major (2001). In a review of this work Sears argues that "the idealistic hope behind much of [the work in this volume] is that subordinate groups will see through the illusory legitimizing myths fostered by dominant groups to a 'true' consciousness more in harmony with their own real interests, and will then mobilize collectively to pursue them" (2003, 320).

My earlier work suggests that there is substantial evidence that legitimacy encourages a wide variety of forms of public cooperation in many, but clearly not all, social settings. Those who support authorities and institutions defer to their decisions and to the policies and rules they create (Tyler 2001b; Tyler and Huo 2002). Hence, the central empirical premise of legitimacy is well supported, and those who view system stability as a valuable attribute can and do benefit when they are able to create and maintain this supportive value. As a consequence, the question of how to view these findings is a socially important one. 
One way of reconciling the consensus and conflict theory perspectives is to understand how legitimacy is created and maintained (Tyler 2006). Findings consistently suggest that the legitimacy of authorities and institutions is linked to the fairness of the procedures by which they exercise their authority. These findings link legitimacy to the degree to which institutions are "just" institutions. Hence, the pursuit of public support requires institutions and authorities to adhere to lay principles of justice. The effort to create and maintain legitimacy, in other words, causes institutions to focus on those who are being led, and their conceptions of procedural justice. It is only when the perspectives of everyday members are enshrined in institutions and in the actions of authorities that widespread legitimacy will exist.

The risk, pointed to by conflict theorists, is that justice judgments themselves will be the result of false consciousness, with the members of subordinate groups adopting the legitimating myths put forward by the dominant class (Fox 1999). An example of this type of myth acceptance has already been noted in research on economic markets. Belief in the procedural justice of markets is widespread within American society, even among those who benefit the least from the markets' operation (Jost, Blount, Pfeffer, and Hunyady 2003). Further, this belief is generally not influenced by evidence that the market operates in ways that lead to wide group-based differences in economic outcomes (Tyler 2004a). These results are consistent with the argument that, in at least some instances, the justice judgments shaping assessments of legitimacy may reflect the perspective of a particular social group.

Two crosscurrents of thinking about legitimacy have emerged in recent years. First, as noted above, critical perspectives on society and social institutions have become much more prevalent within American social psychology. There is a long tradition of suspicion toward authorities and institutions among social scientists writing about the law and legal institutions (Edelman 1964; Scheingold 1974), but not within American social psychology. However, in recent years a critical perspective on legitimacy and procedural justice has emerged (Fox 1999; Haney 1991; Tyler and McGraw 1986). In addition, the development of system justification theory (Jost and Banaji 1994; Jost, Banaji, and Nosek 2004) and social dominance theory (Sidanius and Pratto 1999) have generally moved the issue of "false consciousness" to a more central place within American social psychology (see also Tyler and McGraw 1986; Chen and Tyler 2001).

At the same time, issues of social stability, and the role of institutions and authorities in promoting social order and stability, have become more prominent in the wake of the rise of terrorism. Just as these issues were central to the recreation of societies following the Second World War, and were important to the 
transitions that occurred in South Africa and the former Soviet Union, they are currently of considerable significance to the United States, because of the external threat of terrorism. One key difference is that, while traditional concerns with social stability have focused on creating societies that can manage internal dissention, recent discussions within America have been about creating a society that can combat external threats.

Democracies are especially able to mobilize the energy of their citizens and, hence, are good at winning wars (Reiter and Stam 2002). However, these same social dynamics lead democracies to have difficulty with protracted conflicts, and the war on terrorism is a protracted conflict. It involves being able to mobilize the efforts of American citizens to support the conflict, and being able to convince the members of minority groups within American society who might have sympathy toward terrorists or their ideologies to be willing to work with legal and political authorities to identify and apprehend terrorists.

In other words, two key issues that have already been discussed emerge as central to the fight against terrorism: how to gain widespread public cooperation with social institutions and authorities, and how to secure the loyalty and cooperation of those people within ethnic/religious subgroups who typically have the lowest legitimacy ratings in the population and who potentially have ideological, religious, or ethnicity-based reasons for supporting opposition to American society. And, as is pointed out within discussions of system stability, the government is most in need of this cooperation when it is asking for material sacrifices from citizens and is not in a position to provide people with commensurate benefits. During times of crisis and war the government asks the most and gives the least to its citizens (Levi 1997), and depends on having a "reservoir of support," based on its legitimacy, that it can call upon from citizens.

As is clear from this formulation, while the threat of terrorism to America may be unprecedented in our history, the basic issues raised by it are not. Dealing with terrorism leads to concern with the social dynamics underlying the people, government, and society. It first focuses attention on why most people within American society are loyal to and supportive of society and government. Although terrorists can kill people and damage property, historically terrorists are only successful when they can persuade a large portion of the general population that their cause is legitimate and ought to be embraced and aided (Nye 2002). It is for this reason that terrorists accompany their armed struggle with propaganda. They recognize that unless they can gain a psychological foothold within the general population, they will not prevail. Since the government relies heavily upon the voluntary cooperation of its citizens, it is vulnerable to destabilization if its institutions lose legitimacy. 
Second, the government needs the cooperation of diverse members of society. It is those people who are members of immigrant and disadvantaged groups who are most likely to be drawn to the appeals by terrorists and their calls for aid and comfort. As Mao Tse-Tung said, "The guerrilla must move amongst the people as a fish swims in the sea." Hence, success depends upon being able to find willing havens among people who will provide such aid at considerable risk and cost to themselves.

Consistent with the arguments outlined in Why People Obey the Law, studies find that reward/cost calculations do not explain why people become or support terrorists (Moghaddam 2005; Post 1990; Smelser and Mitchell 2002a; Varshney 2003). As a result, trying to stop people from aiding terrorists by making "credible threats" of punishment is "of limited utility" (Smelser and Mitchell 2002b). What can be effective? The arguments made in Why People Obey the Law have been extended into later studies of the attitudes and behavior of minority group members. They point strongly to procedural justice as a key antecedent of legitimacy and cooperation (Moghaddam 2005).

How are the arguments advanced here relevant to government efforts to fight terrorism? One key issue is the public's willingness to tolerate government intrusiveness into their personal lives in the pursuit of security. Just as research on crime prevention demonstrates that the public reacts negatively to the use of police procedures viewed as unfair, for example, racial profiling (Tyler and Wakslak 2004), the actions of government, if perceived as unjust, may alienate the general population and undermine their support for efforts to combat terrorism. Recognizing the centrality of public support, the government ought to weigh actions against their consequences for public legitimacy, as well as against their likelihood of success in combating terrorism. For policies to be sustainable, they must have public support (Herron and Jenkins-Smith 2003). If they do not, their use undermines legitimacy and public cooperation. These arguments apply even more strongly to the support of members of minority groups.

\section{Social Science versus Normative Perspectives on Legitimacy}

In his classic discussion of legitimacy Weber (1968) distinguishes between a philosophical, or normative, perspective on legitimacy, which asks why people ought to obey the law, and a social science perspective, which asks why people do obey the law. It is the latter approach to legitimacy that is taken in Why People Obey the Law. By using psychological methods of data collection and analysis, the book explores the factors that shape public behavior. The 
question of whether the law is consistent with philosophical or legal standards and ought to be obeyed is not considered. This approach complements efforts toward effective governance, since an understanding of the social dynamics of groups, organizations, and societies provides guidance about which policies are likely to be sustainable and effective within those groups.

The distinction between these two approaches to the law has continued into recent legal scholarship. Fallon (2005) distinguishes between legal (i.e., normative) and sociological (i.e., social science) perspectives on legitimacy, and notes that legitimacy can also be based on consistency with moral values. Fallon argues for the distinct value of both legal and sociological approaches to legitimacy, suggesting that the sociological approach is important because of the concern with maintaining public compliance with the law. Not all legal scholars, however, have viewed social science perspectives so positively. Solum (2004) argues that jurisprudence should be constructed upon a procedural justice foundation, but that that foundation should be defined by normative models, not by social science ones. However, even Solum acknowledges that, "as a pragmatic matter, it is important that citizens be able to regard procedures as legitimate so that we may secure their voluntary cooperation with the system of social justice" (2004, 278-279).

Striking a proper balance between normative and social science perspectives is central to the development of the interface of law and social science, and to the work of law professors (Solum 2004; Fallon 2005), philosophers (Beetham 1991), and social scientists (Tyler and Darley 2000). This effort is key to discussions of legitimacy, but is also important in other areas. For example, recent attempts to develop a social science perspective on rights and duties have grappled with similar questions about the appropriate range of normative and social science concerns (Finkel and Moghaddam 2005).

\section{Summary}

When Why People Obey the Law was written, its focus was upon the management of social order among the residents of a large American city. However, the broader issue it addresses, how to manage social order, has emerged in recent years as a concern in a wide variety of settings. It has been central to discussions about how to deal with disorder in emerging nations throughout the world, and to recent discussions within our own society about how to best combat the external threat posed by terrorism. In addressing all of these issues, Why People Obey the Law makes the argument that the relationship between the members of groups, organizations, and societies and the authorities and institu- 
tions which govern them need not be based upon an instrumental exchange of rewards or be a threat-based approach to social control. It is also possible to engage the values of the population, which leads to a self-regulatory stance toward governance, in which people voluntarily defer to authorities and institutions because they view doing so as part of the obligation they have to their leaders.

\section{References}

Barrett-Howard, E., and Tyler, T. R. 1986. Procedural justice as a criterion in allocation decisions. Journal of Personality and Social Psychology 50: 296-304.

Beetham, D. 1991. The legitimation of power. Atlantic Highlands, N.J.: Humanities Press International.

Casper, J. D., Tyler, T. R., and Fisher, B. 1988. Procedural justice in felony cases. Law and Society Review 22: 483-507.

Chen, E., and Tyler, T. R. 2001. Cloaking power: Legitimizing myths and the psychology of the advantaged. In J. A. Bargh and A. Y. Lee-Chai, eds., The use and abuse of power, 241-261. Philadelphia: Psychology Press.

Colquitt, J. A., Conlon, D. E., Wesson, M., Porter, C. O., and Ng, K. Y. 2001. Justice at the millennium: A meta-analytic review of 25 years of organizational justice research. Journal of Applied Psychology 86: 425-445.

Dahl, R. 1956. A preface to democratic theory. Chicago: University of Chicago Press.

Darley, J., Messick, D., and Tyler, T. R., eds. 2001. Social influences on ethical behavior in organizations. Mahwah, N.J.: Lawrence Erlbaum.

DeCremer, D., and Tyler, T. R. 2005. Managing group behavior: The interplay between procedural justice, sense of self, and cooperation. Advances in Experimental Social Psychology 30: 151-218.

Easton, D. 1965. A systems analysis of political life. Chicago: University of Chicago Press.

Easton, D., and Dennis, J. 1969. Children in the political system. Chicago: University of Chicago Press.

Edelman, M. 1964. The symbolic uses of politics. Urbana: University of Illinois Press.

Environmental Protection Agency. 2002. Adopt your watershed. http://www.epa.gov/ adopt.

Ewick, P., and Silbey, S. S. 1998. The common place of law: Stories from everyday life. Chicago: University of Chicago Press.

Fallon, R. H., Jr. 2005. Legitimacy and the constitution. Harvard Law Review 118: 1787-1853.

Farnsworth, S. J. 2003. Congress and citizen discontent: Public evaluations of the membership and one's own representative. American Politics Research 21: 66-80.

Finkel, N., and Moghaddam, F. M. 2005. The psychology of rights and duties: Empirical 
contributions and normative perspectives. Washington, D.C.: American Psychological Association.

Fox, D. R. 1999. Psycholegal scholarship's contribution to false consciousness about injustice. Law and Human Behavior 23: 9-30.

Gangl, A. 2003. Procedural justice theory and evaluations of the lawmaking process. Political Behavior 25: 119-149.

Gibson, J. L. 2002. Truth, justice, and reconciliation: Judging the fairness of amnesty in South Africa. American Journal of Political Science 46: 540-556.

2004. Overcoming apartheid: Can truth reconcile a divided nation? New York: Russell Sage Foundation.

Gibson, J. L., and Caldiera, G. A. 2003. Defenders of democracy? Legitimacy, popular acceptance, and the South African Constitutional Court. Journal of Politics 65: 1-30.

Gibson, J. L., Caldiera, G. A., and Baird, V. A. 1998. On the legitimacy of national high courts. American Political Science Review 92: 343-358.

Gibson, J. L., Caldiera, G. A., and Spence, L. K. 2003. The Supreme Court and the U.S. presidential election of 2000: Wounds, self-inflicted or otherwise? British Journal of Political Science 33: 535-556.

- 2005. Why do people accept public policies they oppose? Testing legitimacy theory with a survey-based experiment. Political Research Quarterly 58: 187-201.

Green, D. P., and Shapiro, I. 1994. Pathologies of rational choice theory. New Haven: Yale University Press.

Haney, C. 1991. The 14th amendment and symbolic legality: Let them eat due process. Law and Human Behavior 15: 183-204.

Herron, K. T., and Jenkins-Smith, H. C. 2003. U.S. public response to terrorism. Report, George H. W. Bush School of Government and Public Service, Texas A \& M, College Station, Texas.

Hess, R. D., and Torney, J. V. 1967. The development of political attitudes in children. New York: Aldine.

Hibbing, J. R., and Theiss-Morse, E. 2002. Stealth democracy: Americans' beliefs about how government should work. Cambridge: Cambridge University Press.

Hollander-Blumoff, R., and Tyler, T. R. 2005. Procedural justice concerns in negotiation. Unpublished manuscript, New York University Law School.

Huo, Y. J. 2003. Procedural justice and social regulation across group boundaries. Personality and Social Psychology Bulletin 29: 336-348.

Huo, Y. J., Smith, H. J., Tyler, T. R., and Lind, E. A. 1996. Superordinate identification, subgroup identification, and justice concerns: Is separatism the problem, is assimilation the answer? Psychological Science 7: 40-45.

Hyde, A. 1983. The concept of legitimation in the sociology of law. Wisconsin Law Review 1983: 379-426.

Hyman, H. 1959. Political socialization: A study of the psychology of political behavior. New York: Free Press. 
Ivancevich, J. M., Duening, T. N., Gilbert, J. A., and Konopaske, R. 2003. Deterring white-collar crime. Academy of Management Executive 17: 114-127.

Jackson, S., and Fondacaro, M. 1999. Procedural justice in resolving family conflict. Law and Policy 21: 101-127.

Jensen, C. 2003. The more things change, the more they stay the same: Copyright, digital technology, and social norms. Stanford Law Review 56: 531-570.

Jost, J. T., and Banaji, M. R. 1994. The role of stereotyping in system-justification and the production of false consciousness. British Journal of Social Psychology 33: 1-27.

Jost, J. T., Banaji, M. R., and Nosek, B. A. 2004. A decade of system justification theory. Political Psychology 25: 881-919.

Jost, J. T., Blount, S., Pfeffer, J., and Hunyady, G. 2003. Fair market ideology: Its cognitive-motivational underpinnings. Research in Organizational Behavior 25: 53-91.

Jost, J. T., and Major, B. 2001. The psychology of legitimacy: Emerging perspectives on ideology, justice, and intergroup relations. Cambridge: Cambridge University Press.

Kelman, H. C. 1969. Patterns of personal involvement in the national system. In J. Rosenau, ed., International politics and foreign policy, 276-288. Rev. ed. New York: Free Press.

- 2001. Reflections on social and psychological processes of legitimization and delegitimization. In J. T. Host and B. Major, eds., The psychology of legitimacy: Emerging perspectives on ideology, justice, and intergroup relations. Cambridge: Cambridge University Press.

Kelman, H. C., and Hamilton, V. L. 1989. Crimes of Obedience. New Haven: Yale University Press.

Kenney, D. S. 1999. Historical and sociopolitical context of Western watersheds movement. Journal of the American Water Resources Association 35: 493-503.

Kim, W. C., and Mauborgne, R. A. 1991. Implementing global strategies: The role of procedural justice. Strategic Management Journal 12: 125-143.

1993. Procedural justice, attitudes, and subsidiary top management compliance with multinationals' corporate strategic decisions. Academy of Management Journal 36: 502-526.

Landsman, S. 2003. Lay participation in legal processes and the development of democracy. Law and Policy 25: 173-178.

Leach, W. D., and Pelkey, N. W. 2001. Making watershed partnerships work. Journal of Water Resources Planning and Management 127: 378-385.

Leach, W. D., Pelkey, N. W., and Sabatier, P. A. 2002. Stateholder partnerships as collaborative policymaking. Journal of Policy Analysis and Management 21: 645-670.

Levi, M. 1997. Consent, dissent, and patriotism. Cambridge: Cambridge University Press.

Lind, E. A., Huo, Y. J. and Tyler, T. R. 1994. Any justice for all: Ethnicity, gender, and preferences for dispute resolution procedures. Law and Human Behavior 18: 269-290.

Lind, E. A., and Tyler, T. R. 1988. The Social Psychology of Procedural Justice. New York: Plenum.

Lind, E. A., Tyler, T. R., and Huo, Y. 1997. Procedural context and conflict: Variation in 
the antecedents of procedural justice judgments. Journal of Personality and Social Psychology 73: 767-780.

Lipset, S. M. 1959. Some social requisites of democracy. American Political Science Review 53: 69-105.

MacCoun, R. J. 1993. Drugs and the law: A psychological analysis of drug prohibition. Psychological Bulletin 113: 497-512.

Machura, S. 2003. Fairness, justice, and legitimacy: Experiences of people's judges in South Russia. Law and policy 25: 123-150.

Moghaddam, F. M. 2005. The staircase to terrorism. American Psychologist 60: 161-169. Nagin, D. S. 1998. Criminal deterrence at the onset of the 21 st century. Crime and Justice 23: $1-42$.

Nye, J. S. 2002. The Paradox of American Power. Oxford: Oxford University Press.

Parkin, F. 1972. Class inequality and political order. New York: Praeger.

Parsons, T. 1967. Some reflections on the place of force in social process. In T. Parsons, ed., Sociological theory and modern society. New York: Free Press.

Paternoster, R., Brame, R., Bachman, R., and Sherman, L. W. 1997. Do fair procedures matter? Law and Society Review 31: 163-204.

Pfeffer, J. 1994. Competitive advantage through people. Cambridge, Mass.: Harvard University Press.

Post, J. M. 1990. Terrorist psycho-logic. In W. Reich, ed., Origins of Terrorism. Washington, D.C.: Woodrow Wilson Center Press.

Pruitt, D. G., Peirce, R. S., McGillicuddy, N. B., Welton, G. I., and Castrianno, L. M. 1993. Long-term success in mediation. Law and Human Behavior 17: 313-330.

Putnam, R. 2000. Bowling alone: The collapse and revival of American community. New York: Simon and Schuster.

Reiter, D., and Stam, A. C. 2002. Democracies at war. Princeton: Princeton University Press.

Sampson, R. J., Raudenbush, S. W., and Earls, F. 1997. Neighborhoods and violent crime: A multilevel study of collective efficacy. Science 277: 918-924.

Sarat, A. 1993. Authority, anxiety, and procedural justice: Moving from scientific detachment to critical engagement. Law and Society Review 27: 647-671.

Scheingold, S. 1974. The politics of rights. Reprint. Ann Arbor: University of Michigan Press.

Sears, D. O. 2003. The psychology of legitimacy. Political Psychology 25: 318-323.

Selznick, P. 1969. Law, society, and industrial justice. New York: Russell Sage Foundation.

Sidanius, J., and Pratto, F. 1999. Social dominance. Cambridge: Cambridge University Press.

Smelser, N. M., and Mitchell, F. 2002a. Terrorism: Perspectives for the behavioral and social sciences. Washington, D.C.: National Academy Press.

. 2002b. Discouraging terrorism: Some implications of 9/11. Washington, D.C.:

National Academy Press.

For general queries, contact webmaster@press.princeton.edu 
Smith, H. J., and Tyler, T. R. 1996. Justice and power: Can justice motivations and superordinate categorizations encourage the advantaged to support policies which redistribute economic resources and encourage the disadvantaged to willingly obey the law? European Journal of Social Psychology 26: 171-200.

- 1997. Choosing the right pond: The influence of the status of one's group and one's status in that group on self-esteem and group-oriented behaviors. Journal of Experimental Social Psychology 33: 146-170.

Smith, H. J., Tyler, T. R., Huo, Y. J., Ortiz, D. J., and Lind, E. A. 1998. The self-relevant implications of the group-value model: Group membership, self-worth, and procedural justice. Journal of Experimental Social Psychology 34: 470-493.

Solum, L. B. 2004. Procedural justice. Southern California Law Review 78: 181-321.

Sondak, H., and Tyler, T. R. In press. How does procedural justice shape the desirability of markets? Journal of Economic Pyschology.

Sparks, R., Bottoms, A., and Hay, W. 1996. Prisons and the problem of order. Oxford: Clarendon.

Sunshine, J., and Tyler, T. R. 2003. The role of procedural justice and legitimacy in shaping public support for policing. Law and Society Review 37(3): 555-589.

Thibaut, J., and Walker, L. 1975. Procedural justice. Mahwah, N.J.: Erlbaum.

Thucydides. 1982. The Peloponnesian War (Book 5). Trans. T. E. Wick and Richard Crawley. New York: Modern Library.

Trochev, A. 2004. Less democracy, more courts: A puzzle of judicial review in Russia. Law and Society Review 38: 513-548.

Tyler, T. R. 1987a. Conditions leading to value-expressive effects in judgments of procedural justice: A test of four models. Journal of Personality and Social Psychology 52: $333-344$.

- 1987b. The psychology of dispute resolution: Implications for the mediation of disputes by third parties. Negotiation Journal 3: 367-374.

- 1988a. What is procedural justice? Criteria used by citizens to assess the fairness of legal procedures. Law and Society Review 22: 103-135.

- 1988b. Client perceptions of litigation. Trial 24: 40-45.

1989. The psychology of procedural justice: A test of the group value model. Journal of Personality and Social Psychology 57: 830-838.

1994a. Psychological models of the justice motive. Journal of Personality and Social Psychology 67: 850-863.

1994b. Governing amid diversity: Can fair decision-making procedures bridge competing public interests and values? Law and Society Review 28: 701-722.

1997a. Citizen discontent with legal procedures. American Journal of Comparative Law 45: 869-902.

1997b. Compliance with intellectual property laws: A psychological perspective. Journal of International Law and Politics 28: 101-115.

1998. Public mistrust of the law: A political perspective. University of Cincinnati Law Review 66: 847-876. 
2000a. Multiculturalism and the willingness of citizens to defer to law and to legal authorities. Law and Social Inquiry 25(3): 983-1019.

2000b. Social justice. International Journal of Psychology 35: 117-125.

2001a. Public trust and confidence in legal authorities: What do majority and minority group members want from the law and legal authorities? Behavioral Science and the Law 19: 215-235.

. 2001b. A psychological perspective on the legitimacy of authorities and institutions. In J. T. Jost and B. Major, eds., The psychology of legitimacy: Emerging perspective on ideology, justice, and intergroup relations. Cambridge: Cambridge University Press.

- 2002. Leadership and cooperation in groups. American Behavioral Scientist 45: $769-782$.

2003. Procedural justice, legitimacy, and the effectiveness of law. Crime and Justice 30: 431-505.

- 2004a. Affirmative action in an institutional context. Social Justice Research 17: $5-24$.

2004b. Enhancing police legitimacy. The Annals of the American Academy of Political and Social Science 593: 84-99.

- 2005. Promoting employee policy adherence and rule following in work settings:

The value of self-regulatory approaches. Brooklyn Law Review 70: 1287-1312.

2006. Legitimacy and legitimation. Annual Review of Psychology 57: 375-400.

. In press. Process utility and help seeking. Journal of Economic Psychology.

Tyler, T. R., and Blader, S. L. 2000. Cooperation in groups. Philadelphia: Psychology Press.

2003. Procedural justice, social identity, and cooperative behavior. Personality and Social Psychology Review 7: 349-361.

2005. Can businesses effectively regulate employee conduct? The antecedents of rule following in work settings. Academy of Management Journal 48: 1143-1158.

Tyler, T. R., Boeckmann, R. J., Smith, H. J., and Huo, Y. J. 1997. Social justice in a diverse society. Boulder, Colo.: Westview.

Tyler, T. R., Casper, J. D., and Fisher, B. 1989. Maintaining allegiance toward political authorities: The role of prior attitudes and the use of fair procedures. American Journal of Political Science 33: 629-652.

Tyler, T. R., and Darley, J. 2000. Building a law-abiding society: Taking public views about morality and the legitimacy of legal authorities into account when formulating substantive law. Hofstra Law Review 28: 707-739.

Tyler, T. R., and Degoey, P. 1995. Collective restraint in a social dilemma situation: The influence of procedural justice and community identification on the empowerment and legitimacy of authority. Journal of Personality and Social Psychology 69: $482-497$.

Tyler, T. R., Degoey, P., and Smith, H. 1996. Understanding why the justice of group procedures matters: A test of the psychological dynamics of the group-value model. Journal of Personality and Social Psychology 70: 913-930.

For general queries, contact webmaster@press.princeton.edu 
Tyler, T. R., and Huo, Y. J. 2002. Trust in the law. New York: Russell Sage Foundation.

Tyler, T. R., and Lind, E. A. 1992. A relational model of authority in groups. Advances in Experimental Social Psychology 25: 115-191.

Tyler, T. R., Lind, E. A., Ohbuchi, K., Sugawara, I., and Huo, Y. J. 1998. Conflict with outsiders: Disputing within and across cultural boundaries. Personality and Social Psychology Bulletin 24: 137-146.

Tyler, T. R., and McGraw, K. 1986. Ideology and the interpretation of personal experience: Procedural justice and political quiescence. Journal of Social Issues 42: $115-128$.

Tyler, T. R., and Mitchell, G. 1994. Legitimacy and the empowerment of discretionary legal authority: The United States Supreme Court and abortion rights. Duke Law Journal 43: 703-814.

Tyler, T. R., Rasinski, K., and Spodick, N. 1985. The influence of voice on satisfaction with leaders: Exploring the meaning of process control. Journal of Personality and Social Psychology 48: 72-81.

Tyler, T. R., and Smith, H. 1998. Social justice and social movements. In D. Gilbert, S. Fiske, G. Lindzey, eds., Handbook of Social Psychology. 4th ed. Vol. 2. 595-629. New York: McGraw-Hill.

Tyler, T. R., and Thorisdottir, H. 2003. A psychological perspective on compensation for harm: Examining the September 11th Victim Compensation Fund. DePaul Law Review 53: 355-391.

Tyler, T. R., and Wakslak, C. 2004. Profiling and the legitimacy of the police: Procedural justice, attributions of motive, and the acceptance of social authority. Criminology 42 : $13-42$.

Van Vugt, M., Snyder, M., Tyler, T. R., and Biel, A., eds. 2000. Cooperation in modern society: Promoting the welfare of communities, states, and organizations. New York: Routledge.

Varshney, A. 2003. Nationalism, ethnic conflict, and rationality. Perspectives on Politics 1: 85-99.

Weber, M. 1968. Economy and society. Ed. G. Roth and C. Wittich. Berkeley and Los Angeles: University of California Press.

Zelditch, M., Jr. 2001. Processes of legitimation: Recent developments and new directions. Social Psychology Quarterly 64: 4-17.

Zelditch, M., Jr., and Walker, H. A. 2003. The normative regulation of power. Advances in Group Processes 17: 155-178. 